\title{
Pengaruh Pemberian Biomassa Talas dengan Kadar yang Berbeda Dalam Ransum Itik Lokal (Anas Domesticus) Terhadap Produksi dan Berat Telur
}

\section{The Effect Of Giving Different Levels Of Taro Biomass In Local Duck Rations (Anas Domesticus ) On Egg Production And Weight}

\author{
Tri Purwanto*, Muh. Jurhadi Kadir, Nurhaedah \\ Program Studi Peternakan, Fakultas Pertanian, Peternakan dan Perikanan, \\ Universitas Muhammadiyah Parepare, 91132, Sulawesi Selatan, Indonesia \\ *Korespondensi E-mail: tripurwanto.pur1996@gmail.com
}

\begin{abstract}
ABSTRAK
Penelitian ini bertujuan untuk mengetahui pengaruh penambahan biomassa talas dengan level yang berbeda dalam ransum itik lokal terhadap produksi dan berat telur. Penelitian pakan alternatif daun talas menggunakan rancangan acak lengkap (RAL) dengan 4 perlakuan dan 3 ulangan, P0 : 100\% ransum tanpa penambahan talas, sebagai kontrol P1 : 85\% ransum basal + biomassatalas 15\%, P2 : 80\% ransum basal + biomassa talas $20 \%$ P3 : 75\% ransum basal + biomassa talas $25 \%$ Hasil penelitian menunjukkan bahwa hasil produksi telur dan berat telur itik lokal (Anas domesticus) dengan penambahan biomassa talas pada ransum mengalami peningkatan, memberikan pengaruh yang sangat nyata. Rata-rata produksi telur tertinggi ke terendah yaitu P3 sebesar (12,86), P2 sebesar $(12,46)$, P1 sebesar $(12,06)$, dan P0 sebesar $(11,60)$. Hasil Berat telur itik dari rendah ke tertinggi yaitu P2sebesar $(26,04)$, P3 sebesar $(29,13)$, P0 sebesar $(29,14)$ dan P1 sebesar $(29,42)$. Dari hasil penelitian maka diketahui bahwa perlakuan terbaik yang dapat direkomendasikan yaitu perlakuan P3 dengan $(12,86)$ untuk produksi telur dan P1 $(29,42)$ untuk berat telur.
\end{abstract}

Kata kunci: Talas (Colocasia esculenta), Produksi Telur, Berat Telur, Itik Lokal (Anas domesticus)

\begin{abstract}
This study aims to determine the effect of the addition of taro biomass with different levels in the local duck ration on egg production and wight. The results showed that the results of egg production and weight of local duck eggs (Anas domesticus) with the addition of taro biomass to the ration had increased, giving a very real effect. The highest average egg production to the lowest is P3 $(12,86)$, $\mathrm{P} 2$ is $(12,46), \mathrm{P} 1$ is $(12,06)$, and P0 $(11,60)$. Results weight of duck egg from low to highest is P2 of (29.04), P3 of $(29,13), \mathrm{PO}$ of $(29,14)$, and P1 of $(29,42)$. From the results of study it is known that the best treatment that can be recommended is the treatment of P3 for egg production and P1 for egg weight.
\end{abstract}

Keywords: Taro (Colocasia esculenta), Egg Production, Egg Weight, Local Ducks (Anas domesticus) 


\section{PENDAHULUAN}

Pemanfaatan limbah pertanian berupa daun, batang, dan kulit buah di ransum ternak unggas belum maksimal seperti pemanfaatannya ke ternak besar.Pemberian limbah pertanian diransum unggas hanya sebatas untuk pemeliharaan ternak unggas secara tradisional, sehingga hasil dari usaha peternakan ini belum maksimal.Limbah pertanian berupa daun, batang, dan kulit buah dapat di manfaatkan sebagai pakan ternak unggas karena mengandung banyak beta-karoten yang berfungsi untuk meningkatkan pertumbuhan dan produksi pada unggas.maka dari itu beta-karoten penting untuk di manfaatkan.

Salah satu bahan pakan yang dapat digunakan sebagai bahan pakan alternatif sehingga dapat menggantikan atau mengurangi penggunaan bahan pakan konvensional adalah penggunaan talas pada pakan itik.Talas merupakan tanaman yang masih banyak dijumpai tumbuh liar di daerah berawa.Beberapa peternak itik di Bengkulu dijumpai telah menggunakan talas sebagai campuran pakan itik yang diyakini dapat meningkatkan produksi telur itik. Talas dengan nama latin Colocasia esculenta L., merupakan tumbuhan penghasil umbi yang cukup penting. Berasal dari Asia Tenggara atau Asia Tengah bagian selatan, talas diperkirakan telah dibudidayakan oleh manusia sejak masa purba, bahkan sebelum padi ditanam orang. Talas bisa tumbuh $50 \mathrm{~cm}$ tinggi bahkan hingga 2 meter, dan ternyata didalam talas mengandung banyak kesehatan dari daun talas, kulit dan umbinya.

Perkembangan peternakan itik lokal sangat didukung oleh kemampuan itik mencerna bahan pakan lokal dengan kadar serat yang lebih tinggi serta ketersediaan berbagai alternatif dan suplai bahan pakan lokal tersebut. Namun, sampai saat ini kendala utama dalam pengembangan peternakan itik lebih lanjut adalah ketersediaan bibit dari segi kuantitas maupun kualitas, karena sistem pengadaan bibit yang ada selama ini masih sangat terbatas dan hanya dikelola secara sederhana dan tradisional.Oleh karena itu, perlu adanya upaya pengembangan bibit komersial (bibit unggul) yang lebih menguntungkan dan sistem pembibitan itik lokal secara baik dan terarah, dengan dukungan teknologi yang telah dihasilkan dari berbagai penelitian.

Perubahan faktor lingkungan mendorong terjadinya pergeseran dalam sistem pemeliharaan itik di Indonesia, dari ekstensif tradisional ke arah sistem pemeliharaan yang lebih intensif dan terkurung. Faktor-faktor tersebut antara lain adalah makin terbatasnya lahan penggembalaan itik, adanya wabah flu burung dimana itik bisa menjadi pembawa 
virusnya, dan makin terbukanya pasar untuk berbagai produk itik. Adanya perubahan ini menuntut tersedianya bibit yang lebih baik dan dengan produktivitas yang lebih tinggi, agar peternak dengan sistem intensif dan dengan biaya produksi yang lebih tinggi tetap dapat memperoleh keuntungan dalam melakukan budidayanya.

Bahan yang digunakan untuk pakan ternak itik lokal ini yaitu daun talas, karena daun talas ini mengandung protein lebih tinggi dari umbinya dan pada talas bogor, talas semir dan talas bentul kandungan protein kasar berat kering daun adalah 4,24\%-6,99\% sedangkan pada umbinya sekitar $0,54 \%-3,55 \%$ serta daun talas mengandung polifenol dan tangkai daun mengandung saponin.

Penelitian ini dirancang untuk mengevaluasi pengaruh pemberian talas (Colocasia esculenta L.) terhadap produksi telur itik lokal dan berat telur itik lokal.

\section{METODE}

Penelitian pakan alternatif daun talas menggunakan rancangan acak lengkap (RAL) dengan 4 perlakuan dan 3 ulangan. Adapun formulasi pakan alternatif daun talas sebagai perlakuan dalam penelitian ini adalah P0 (100\% ransum basal tanpa penambahan talas, sebagai kontrol), P1 (85\% Ransum Basal + Biomassa Talas 15\%), P2 (80\% Ransum Basal + Biomassa Talas $20 \%$ ) dan P3 (75\% Ransum Basal + Biomassa Talas 25\%), dengan jumlah itik dalam satu kandang terdiri dari 5 ekor dengan luas kandang 3 meter per kandang.

\section{Teknik Pemberian Pakan}

Daun, tangkai talas dicuci, dicacah-cacah berukuran sekitar $2 \mathrm{~cm}$, untuk selanjutnya dikukus selama sepuluh menit, setelah dingin daun dicampur dengan ransum dengan proporsi sesuai perlakuan, ransum di berikan 2 kali sehari, pagi pada pukul 7.00 WITA dan sore pada pukul 16.00 WITA, sedangkan air minum diberikan ad libitum.

Proses adaptasi ternak dengan pakan yaitu selama 1 minggu tujuan dari proses ini yaitu untuk membuat ternak beradaptasi dengan pakan yang telah di campur dengan daun talas dan memungkin meningkatkan palatabilitas terhadap pakan tersebut.

\section{Analisis Data}

Data yang diperoleh dari panelitian ini dihitung dengan menggunakan rancangan acak lengkap (RAL). Apabila perlakuan berpengaruh nyata akan dilanjutkan dengan uji jarak wilayah berganda duncan, data di analisis dengan bantuan program SPSS. 


\section{HASIL DAN PEMBAHASAN}

\section{Produksi Telur}

Hasil penelitian menunjukkan bahwa hasil produksi telur itik lokal (Anas domesticus) dengan penambahan biomassa talas pada ransum mengalami peningkatan. Hal ini dapat dilihat pada Gambar 1.

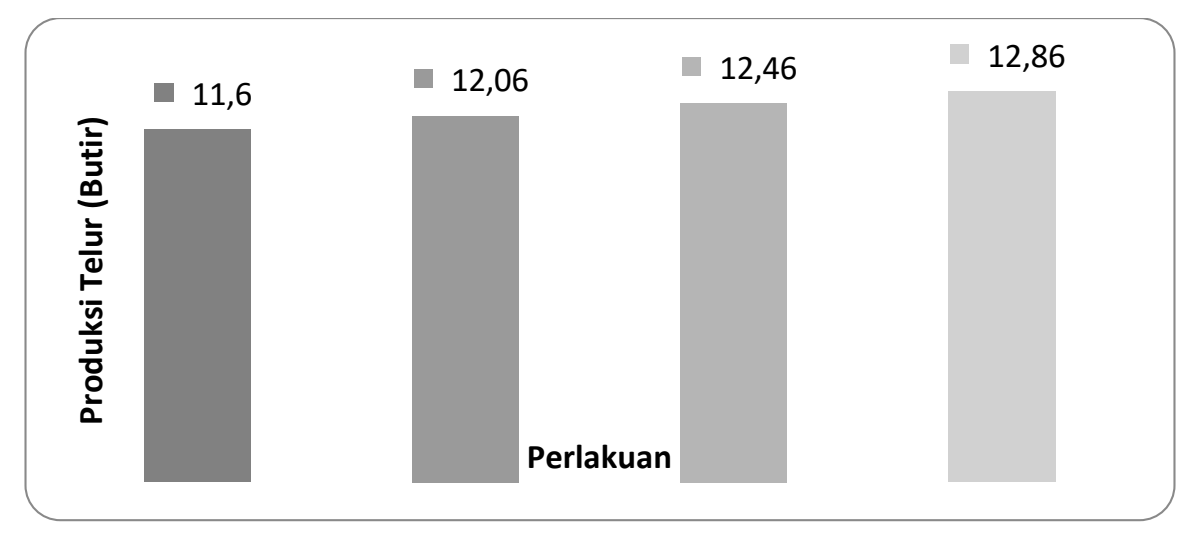

Gambar 1. Rata-rata Produksi Telur Penambahan Biomassa Talas dengan Level Berbeda Dalam Ransum Itik Lokal

Penggunaan talas dalam berbagai kombinasi antara daun, dan tangkai daun, pada ransum itik yang sedang produksi tidak berefek negatif terhadap produksi telur. Nilai ratarata produksi telur itik lokal (Anas domesticus) dengan penambahan biomassa dalam ransum dari yang terendah ke tertinggi adalah P0 (11,60\%), P1(12,06\%), P2 (12,46\%), P3 (12,86\%).

Hasil analisis ragam menunjukkan bahwa perlakuan pemberian talas berpengaruh tidak nyata $(\mathrm{P}>0,05)$ terhadap persentase produksi telur. Persentase produksi telur itik paling tinggi terdapat pada perlakuan P3 yang diberi talas 25\%, yaitu 12,86\% dibandingkan perlakuan lainnya. Rendah persentase produksi telur pda perlakuan selain P3, diduga jumlah konsumsi pakan yang rendah sehingga asupan protein juga rendah. Sehingga, kondisi ini belum dapat memenuhi asam asam amino yang dibutuhkan oleh itik yang sedang berproduksi, Kemungkinan lain adalah kandungan asam-asam amino talas diduga tidak selengkap bahan pakan yang berasal dari hewani. Menurut Subowo (2002) bahwa, susunan asam amino yang sangat penting bagi unggas, seperti arginin, tryptophan dan tyrosin yang sangat kurang dalam bahan pakan yang lain. Penggunaan talas menurut Kusnandar et al., (2007) dapat meningkatkan kecernaan sehingga berdampak positif 
terhadap produksi telur. Selain protein dan energi, nutrien yang mempengaruhi produktivitas adalah mineral (NRC, 1994). Diketahui bahwa bakteri asam laktat terutama dari kelompok Bifidobakteria dan beberapa spesies Laktobasili mempunyai peranan penting dalam menjaga fungsi fisiologis dan kesehatan. Talas yang merupakan tanaman asli daerah tropis dapat dimanfaatkan sebagai pakan itik karena kandungan gizi talas tersebut. Vincent dan Yamaguchi (1998) menyatakan, talas mengandung kalsium, vitamin A, dan vitamin C yang jauh lebih baik dibandingkan dengan beras dan gandum. Setiap 100 gram talas mengandung protein 1,9 g, lemak 0,2 g, karbohidrat 23,7 g, kalsium $28 \mathrm{mg}$, fosfor $61 \mathrm{mg}$, zat besi $1 \mathrm{mg}$, vitamin A $20 \mathrm{mg}$, vitamin B1 0,13 mg, vitamin C $4 \mathrm{mg}$, dan air 73 g. Selain mengandung zat gizi, talas juga mengandung anti nutrisi glukosida sianogenik.

\section{Berat Telur}

Hasil berat telur itik lokal (Anas domesticus) dengan penambahan biomassa talas dengan level yang berbeda dalam ransum itik lokal (Anas domesticus) terhadap berat telur yaitu dapat di lihat pada Gambar 2.

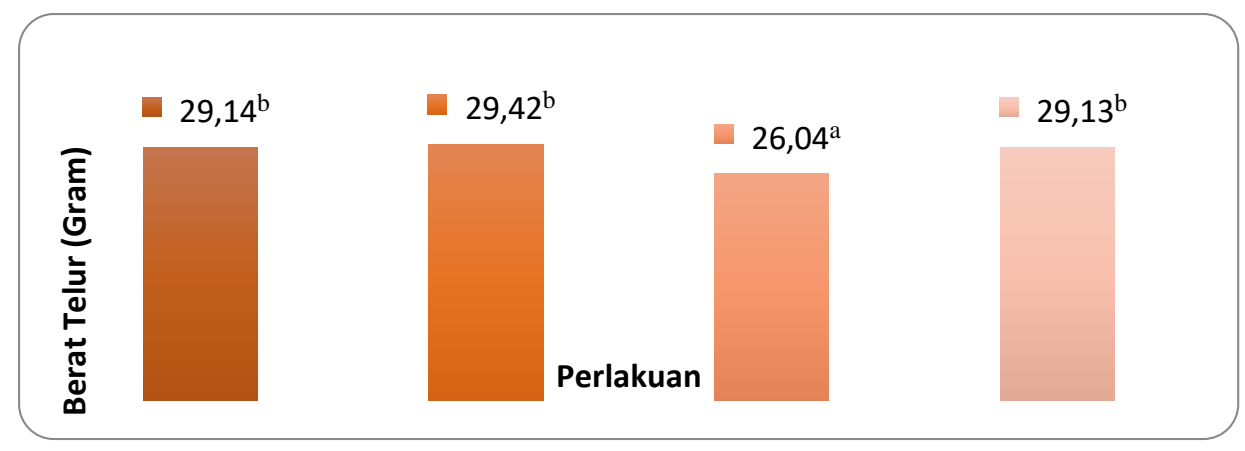

Gambar 2. Rata-Rata Berat Telur Penambahan Biomassa Talas dengan Kadar Berbeda dalam Ransum Itik Lokal

Hasil analisis ragam menunjukkan bahwa perlakuan pemberian talas dengan berbagai kombinasi berpengaruh nyata $(\mathrm{P}<0,05)$ terhadap total berat telur yang dihasilkan Hasil yang diperoleh menunjukkan bahwa penggunaan talas dengan berbagai kombinasi bagian daun, dan tangkai daun talas tidak berdampak negatif terhadap berat telur. Perlakuan P0 tidak berbeda nyata dengan P1 dan P3 namun berbeda nyata dengan perlakuan P2 dan P2 berbeda nyata dengan P0, P1 dan perlakuan P3. Nilai rata-rata berat telur itik lokal (Anas domesticus) dengan penambahan biomassa talas dalam ransum dari terendah ketertinggi adalah P2 (26,04\%), P3 (29,13\%), P0 (29,14\%), P1 (29,42\%). 
Berat total telur P1 dengan 15\% talas, yaitu 29,42\% lebih tinggi dibandingkan perlakuan pemberian kombinasi bagian talas lainnya maupun kontrol, hal ini disebabkan oleh tingkat konsumsi pakan. Menurut Akbarillah (2010) bahwa tingkat konsumsi pakan itik akan mempengaruhi berat telur itik, semakin tinggi konsumsi pakan maka berat telur itik lebih berat.

Faktor lain yang mempengaruhi berat telur, yaitu genetik, pakan, umur, jenis ternak, perubahan musim ketika ternak bertelur dan bobot badan ternak (Sulaiman dan Rahmatullah, 2011). Wahju (2004) menyatakan bahwa kualitas pakan yang baik dalam hal ini kandungan protein, asam amino dan asam linoleat akan mempengaruhi berat telur, karena pakan dengan kualitas yang baik akan menghasilkan telur yang besar. Peningkatan berat telur dapat terjadi karena kandungan asam amino dalam ransum sesuai dengan kebutuhan. Pernyataan ini diperkuat juga oleh Suwindra (1998) yang menyatakan bahwa dengan tingkat protein ransum sekitar 16\%-20\% memperlihatkan hasil positif terhadap itik yaitu mampu meningkatkan produktifitas telur dan bobot telur. Berat telur menjadi sangat penting untuk diperhatikan, karena untuk menunjang nilai jual telur di pasaran dan telur yang besar banyak diminati oleh konsumen, sehingga berpengaruh pula terhadap pendapatan peternak itik (Malik dan Gunawan, 2008). Oleh karena itu, penurunan bobot telur dapat terjadi karena kandungan asam amino dalam ransum tidak sesuai dengan kebutuhan besar kecilnya ukuran telur unggas sangat dipengaruhi oleh kandungan protein dan asam amino essensial dalam pakan (Latifah, 2007). selain faktor tersebut asam amino yang terdapat dalam pakan harus sesuai dengan kebutuhan ternak itik hal ini sejalan dengan pernyataan Parkust dkk (1998) yang menyatakan bahwa, asam amino khususnya methionin dan linoleat sangat berpengaruh besar terhadap ukuran telur, Selain itu peningkatan kandungan kalsium dalam pakan sangat efektif untuk meningkatkan konsumsi pakan sehingga mengoptimalkan produksi telur dan berat telur (Oderkirk, 2001).

\section{KESIMPULAN}

Berdasarkan hasil penelitian, maka dapat disimpulkan sebagai berikut :

1. Penambahan biomassa talas dengan level yang berbeda pada ransum itik lokal (Anas domesticus) tidak berpengaruh terhadap persentase produksi telur

2. Penambahan biomassa talas dengan kadar yang berbeda pada ransum itik lokal (Anas domesticus) berpengaruh terhadap persentase berat telur. 
Tri Purwanto dkk., 41

JiiP Volume 6 Nomor 1: 35-41, Juni 2020

Perlu adanya penelitian lanjutan tentang konsumsi pakan dan konversi ransum, serta nilai ekonomis penggunaan biomassa talas dengan kadar yang berbeda pada ransum itik lokal.

\section{DAFTAR PUSTAKA}

Akbarillah, T., Kususiyah dan Hidayat. 2010. Pengaruh penggunaan daun indigofera segar sebagai suplemen pakan terhadap produksi dan warna yolk itik. Jurnal Sains Peternakan Indonesia, 5(1),

Latifah, R. 2007. The Increasing of Afkir Duck's Egg Quality With Pregnant Mare's Serum Gonadotropin (Pmsg) Hormones. The way to increase of layer duck. 4:1-8

Malik, A. dan A. Gunawan. 2008. Efek Penyuntikan Dosis Rendah Hormon Gonadotropin Terhadap Besar Telur Itik Mojosari. Fakultas Pertanian Universitas Islam Kalimantan (Uniska). Banjarmasin. Jurnal Ilmu Ternak, 8 (1), 91-94.

Oderkirk, A. 2001.The Role of Calcium Phosphorus and Vitamin D3 in Egg Shell and Bone Formation. Nova Scotia Department of Agriculture and Marketing.

Kusnandar, F., Nuraida, L., dan Palupi, N.S. 2007. Pemanfaatan talas, garut dan sukun sebagai prebiotik dan formulasi simbiotik sebagai suplemen pangan. Ilmu dan Teknologi Pangan-FATETA. Lab IPB.

National Research Council. 1994. Nutrient Requirement of Poultry. National Academy Press, Washington, D.C.

Sulaiman, A. dan Rahmatullah, S.N. 2011. Karakteristik eksterior, produksi dan kualitas telur itik alabio (Anas platyrhynchos Borneo) di sentra peternakan itik Kalimantan Selatan. Bioscientiae, 8(2), 46-61.

Suwindra.I.N. 1998. Uji tingkat protein pakan terhadap kinerja itik umur 16-40 minggu yang dipelihara intensif pada kandang tanpa dan dengan kolam. Desertasi. Program Pascasarjana Institut Pertanian Bogor, Bogor.

Subowo. 2002. Histologi Umum. edisi ke 2. Penerbit Bumi Aksara, Jakarta

Vincent, E. R. dan M. Yamaguchi. 1998. Sayuran Dunia I. Prinsip, Produksi dan Gizi. Edisi dua. ITB. Bandung.

Wahju, J. 2004. Ilmu Nutrisi Unggas. Gadjah Mada University Press, Yogyakarta. 